\title{
Pengaruh Leaflet Terhadap Pengetahuan Dan Sikap Siswi Dalam Swamedikasi Dismenore Dengan Obat Tradisional (Jamu Kunyit Asam) Di Sma Negeri 3 Pemalang Tahun 2021
}

\author{
Wike Puspita Sari ${ }^{1}$, Siti Rahmatullah ${ }^{2 *}$, Wirasti ${ }^{3}$, Ainun Muthoharoh ${ }^{4}$, \\ 1,2,3,4 Program Studi Sarjana Farmasi, Fakultas Ilmu Kesehatan, Universitas Muhammadiyah \\ Pekajangan Pekalongan, Indonesia \\ *email: amma88.an@gmail.com penulis korespondensi
}

\begin{abstract}
Dysmenorrhea is a problem that is quite often experienced by young women. This pain usually occurs in the lower abdomen, some even experience nausea, vomiting, or diarrhea. How to overcome dysmenorrhea by consuming herbal ingredients such as sour turmeric drink (jamu kunyit asam). The sour turmeric drink contains curcumin, essential oils, anthocyanins which can reduce pain levels. The purpose of this study was to determine the knowledge and attitudes of female students during the pretest and posttest in self-medication of dysmenorrhea with traditional medicine (jamu kunyit asam) at SMA Negeri 3 Pemalang. The method used in this study is a qualitative method with a simple random sampling design using a pretest and posttest with a total of 196 students in class X and XI at SMA Negeri 3 Pemalang. Data were analyzed by univariate and bivariate. The results showed that firstly, there was a significant difference between students knowledge during the pretest and after the posttest with the value of Sig. (2-tailed) $0.000<(0.05)$, which means that there is an effect of leaflet media on students' knowledge of self-medication of dysmenorrhea with traditional medicine (jamu kunyit asam). Second, there is a significant difference between the attitudes of the students during the Pretest and after the Posttest with the value of sig. (2tailed) $0.046<(0.05)$, which means that there is an influence of leaflet media on students' attitudes in overcoming dysmenorrhea self-medication with traditional medicine (jamu turmeric acid). From the results of this study, it was concluded that the role of leaflet media as a means of supporting education for self-medication of dysmenorrhea gave an influence in increasing the knowledge and attitudes of students in self-medication of dysmenorrhea with traditional medicine (jamu kunyit asam).
\end{abstract}

Keywords: Dysmenorrhea, Traditional Medicine, Knowledge, Attitude, Self-medication

\begin{abstract}
Abstrak
Dismenore merupakan salah satu permasalahan yang cukup sering dialami oleh remaja putri. Rasa nyeri atau rasa sakit ini biasanya terjadi pada perut bagian bawah. Cara mengatasi dismenore dengan mengkonsumsi bahan herbal seperti minuman kunyit asam. Minuman kunyit asam mengandung curcumin, minyak atsiri, anthocyanin yang dapat menurunkan tingkat nyeri. Tujuan dari penelitian ini untuk mengetahui pengetahuan dan sikap siswi saat Pretest dan Posttest dalam swamedikasi dismenore dengan obat tradisional (jamu kunyit asam) di SMA Negeri 3 Pemalang. Metode yang digunakan adalah metode kualitatif dengan rancangan simple rondom sampling menggunakan pretest dan postest dengan responden berjumlah 196 siswi kelas X dan XI di SMA Negeri 3 Pemalang. Data dianalisis secara univariat dan bivariat. Hasil penelitian menunjukkan bahwa pertama terdapat perbedaan yang signifikan antara pengetahuan siswi saat Pretest dan sesudah dilakukan Posttest dengan nilai Sig. (2-tailed) 0,000 < (0,05), Kedua terdapat perbedaan yang signifikan antara sikap siswi saat Pretest dan sesudah dilakukan Posttest dengan nilai Sig. (2-tailed) 0,046 < $(0,05)$, yang berarti ada pengaruh media leaflet terhadap pengetahuan dan sikap siswi dalam mengatasi swamedikasi dismenore dengan obat tradisional (jamu kunyit asam). Dari hasil
\end{abstract}




\section{Prosiding Seminar Nasional Kesehatan Lembaga Penelitian dan Pengabdian Masyarakat Universitas Muhammadiyah Pekajangan Pekalongan}

penelitian ini disimpulkan bahwa peran media Leaflet sebagai alat pendukung edukasi swamedikasi dismenore memberikan pengaruh dalam peningkatan pengetahuan dan sikap siswi dalam swamedikasi dismenore dengan obat tradisional (jamu kunyit asam).

Kata kunci: Dismenore, Obat Tradisional, Pengetahuan, Sikap, Swamedikasi

\section{Pendahuluan}

Dismenore merupakan salah satu permasalahan yang cukup sering dialami oleh remaja putri. Rasa nyeri atau rasa sakit ini biasanya terjadi pada perut bagian bawah, bahkan ada pula yang merasakan mual, muntah atau diare. Meskipun dismenore bukan merupakan suatu penyakit tetapi jika hal ini dibiarkan dapat mengganggu aktifitas sehari-hari. Gangguan menstruasi ini biasanya disertai dengan rasa nyeri, kram pada bagian perut bawah. Gejala yang mulai muncul di hari pertama dan akan menghilang di 1-2 hari kemudian, biasanya dijumpai pada usia 15-24 tahun dan pada wanita yang belum pernah melahirkan anak sebelumnya [1].

Swamedikasi dapat dilakukan dengan obat bebas, obat bebas terbatas maupun obat tradisional yang bisa didapat tanpa menggunakan resep dokter. Dalam penggunaannya sesuai dengan keterangan yang terdapat pada kemasan. Swamedikasi dilakukan untuk mengobati suatu penyakit yang ringan [2].

Hasil survei World Health Organization (WHO) menunjukkan lebih dari $80 \%$ wanita usia subur mengalami dismenore ketika haid, 67,2 \% terjadi pada kelompok umur 13 - 21 tahun [3]. Data RISKESDAS Kementrian Kesehatan Republik Indonesia tahun 2013, angka kejadian dysmenorrhea 64,25\% dari total wanita usia subur dan $78,6 \%$ merupakan kelompok remaja awal. Banyak faktor yang menjadi pencetus terjadinya dismenore namun faktor endokrin memegang peran penting pada penyebab terjadinya dismenore dikarenakan saat mengalami menstruasi sel-sel endometrium mengeluarkan prostaglandin. Ramuan atau produk herbal atau fitofarmaka saat ini memang sedang menjadi alternatif utama bagi para remaja putri yang ingin mengurangi rasa nyeri tanpa mendapat efek samping. Minuman kunyit asam memiliki kandungan bahan aktif curcumin yang berfungsi sebagai analgetika, antipiretika, dan antiinflamasi. Dijelaskan pada penelitian yang dilakukan [4]. bahwa kandungan curcumin pada kunyit dan anthocyanin pada asam jawa akan menghambat reaksi Cyclooxygenase (COX-2). Sehingga dapat menghambat atau mengurangi terjadinya inflamasi [5].

Mengatasi rasa sakit akibat dismenore, tidak jarang wanita yang melakukan pengobatan sendiri (swamedikasi) untuk mengatasi dismenore yang dialaminya. Secara sederhana swamedikasi adalah upaya seseorang dalam mengobati gejala sakit atau penyakit tanpa berkonsultasi dengan Dokter terlebih dahulu. Namun bukan berarti asal mengobati, justru pasien harus mencari informasi obat yang sesuai dengan penyakitnya. Tetapi, tidak semua dari wanita yang mengetahui swamedikasi apa yang harus dilakukan pada saat dismenore. Kebanyakan dari mereka banyak yang mengkonsumsi obat-obatan kimia. Padahal masih banyak tumbuhan disekitar lingkungan yang bisa dimanfaatkan untuk mengobati rasa sakitnya akibat dismenore. Pengobatan tradisional lebih aman dibanding pengobatan kimia karena menggunakan bahan alam yang memiliki efek samping lebih kecil [1]. 


\section{Prosiding Seminar Nasional Kesehatan 2021 Lembaga Penelitian dan Pengabdian Masyarakat Universitas Muhammadiyah Pekajangan Pekalongan}

Salah satu tumbuhan herbal yang menjadi alternatif untuk mengatasi Dismenore yaitu kunyit dan asam jawa, secara alamiah kunyit dan asam jawa dipercaya memiliki kandungan senyawa aktif curcumin dan anthocyanin [6]. Contoh tanaman herbal yang dapat digunakan sebagai pereda nyeri haid atau untuk mengobati nyeri haid yaitu Asam Jawa (Tamarindus indica), kunyit (Curcumae domesticae rhizoma), Jahe (Zingiberis rhizoma), madu (Honey) [7].

Kunyit memiliki kandungan curcumin dan minyak atsiri yang mempunyai efek hampir sama dengan obat - obatan golongan analgesik yang dapat menurunkan nyeri dismenore dengan cara menghambat pembentukan prostalglandin dengan mekanisme memblokade impuls-impuls nyeri yang berasal dari korteks nyeri yang ada di medulla oblongata [8].

Asam jawa mengandung anthocyanin dan tanin yang mempunyai efek tidak jauh berbeda dengan obat-obatan golongan anti prostaglandin non steroid dalam menurunkan nyeri dengan cara mengurangi ketegangan otot sehingga dapat menurunkan kram otot pada miometrium saat menstruasi [9].

Pada hasil penelitian [1]. menyebutkan bahwa hampir semua siswi mengetahui mengenai pengetahuan obat herbal. Responden yang mengetahui tentang pengetahuan dismenore dan swamedikasi menggunakan obat herbal kunyit dan asam jawa diketahui hasil yaitu terdapat 60,4775 \% termasuk dalam kategori cukup karena persentase $<75 \%$.

Dari latar belakang tersebut peneliti ingin melakukan penelitian terkait bagaimana pengaruh leaflet terhadap pengetahuan dan sikap siswi dalam swamedikasi dismenore dengan obat tradisional (jamu kunyit asam) di SMA negeri 3 pemalang tahun 2021.

\section{Metode}

Jenis penelitian ini adalah Pra experimental dengan menggunakan rancangan penelitian one group pretest - posttest design. Pengambilan data dilakukan dua kali pada responden yang sama yaitu sebelum (pretest) dan sesudah (posttest) pemberian edukasi. Penelitian dilakukan hari Kamis tanggal 03 Juni sampai hari Selasa tanggal 08 Juni 2021. Tempat penelitian di SMA Negeri 3 Pemalang, Kecamatan Pemalang, Kabupaten Pemalang.

Sampel penelitian ini adalah siswi SMA Negeri 3 Pemalang kelas $X$ dan XI pada tahun 2021 sebanyak 385 siswi. Teknik pengambilan sampel pada penelitian ini menggunakan probability sampling dengan simple rondom sampling atau secara acak. Jumlah sampel yang diambil dalam penelitian ini menggunakan rumus Slovin sebagai berikut.

$$
\mathrm{n}=\mathrm{N} / \mathbf{1}+\mathrm{Ne}^{2}
$$

$\begin{array}{ll}\text { Keterangan } & : \mathrm{n}=\text { Jumlah sampel } \\ \mathrm{N} & =\text { Jumlah populasi } \\ \mathrm{e} 2 & =\text { derajat kepercayaan } \\ \mathrm{N} & =385 /(1+385.0,052) \\ \mathrm{N} & =196 \text { Responden }\end{array}$




\section{Prosiding Seminar Nasional Kesehatan Lembaga Penelitian dan Pengabdian Masyarakat Universitas Muhammadiyah Pekajangan Pekalongan

Alat pengumpulan data menggunakan kuesioner yang telah tervalidasi dan leaflet tentang swamedikasi dismenore dengan obat tradisional (jamu kunyit asam). Kuesioner pengetahuan berjumlah 22 pernyataan dan kuesioner sikap berjumlah 12 pertanyaan skala pengukuran yang digunakan yaitu skala Guttman. Kuesoner ini disediakan jawaban "Benar" dan "Salah", dimana pada pernyataan favorable jawaban "Benar" diberi nilai 1 dan jawaban "Salah" diberi nilai 0. Pada pernyataan unfavorable jawaban "Benar" diberi nilai 0 dan jawaban "Salah" diberi nilai 1 . Data yang diperoleh dilakukan analisis univariat untuk melihat distribusi frekuensi masing-masing variabel, kemudian dilakukan analisis bivariat menggunakan uji wilcoxon untuk mengetahui pengaruh leaflet terhadap pengetahuan dan sikap siswi dalam swamedikasi dismenore dengan oba tradisional (jamu kunyit asam).

\section{Hasil dan Pembahasan}

\section{Hasil}

Penelitian ini dilakukan mulai tanggal 3 Juni - 8 Juni pada 12 kelas yaitu kelas $X$ dan XI. Tempat penelitian di SMA Negeri 3 Pemalang analisis yang digunakan adalah analisi univariat untuk melihat distribusi frekuensi masing-masing variabel, kemudian dilakukan analisis bivariat menggunakan uji wilcoxon untuk mengetahui pengaruh leaflet terhadap

pengetahuan dan sikap siswi dalam swamedikasi dismenore dengan oba tradisional (jamu kunyit asam).

\section{Karakteristik Responden}

Karakteristik responden menunjukkan bahwa responden berusia 16 tahun (54,1\%), kelas XI (59,2\%), siswi berdasarkan lama menstruasi 3-7 hari $(94,4 \%)$, siswi yang mengalami dismenore $(91,8 \%)$, sumber informasi melakukan pengobatan dismenore dari orang tua dan teman $(36,2 \%)$, derajat dismenore dengan nyeri ringan $(51,5 \%)$, tidak berobat ke Dokter pada saat dismenore $(91,8 \%)$.

Tabel 1. Data Karakteristik Responden

\begin{tabular}{|c|c|c|c|}
\hline No & Kariabel & $\mathbf{N}$ & $9 \%$ \\
\hline \multirow[t]{4}{*}{1.} & Usia & & \\
\hline & 15 tabun & 18 & 9,2 \\
\hline & 16 tabun & 106 & 54,1 \\
\hline & 17 tabun & 72 & 36,7 \\
\hline \multirow[t]{3}{*}{2.} & Kelas & & \\
\hline & $\times$ & 80 & 48,8 \\
\hline & $x_{I}$ & 116 & 59,2 \\
\hline \multirow[t]{4}{*}{3.} & Lama Menstruasi & & \\
\hline & $3-7$ bari & 185 & 94,4 \\
\hline & 14 bari & 9 & 4,6 \\
\hline & lebib dari 14 hari. & 2 & 1 \\
\hline \multirow[t]{3}{*}{4.} & Menclalami Dismenoce & & \\
\hline & Doencalami dismenore & 180 & 91,8 \\
\hline & Iidak Rernab dismenore & 16 & 8,2 \\
\hline \multirow[t]{6}{*}{6} & $\begin{array}{l}\text { Sumber Informasi Rengabatan. } \\
\text { Dismenore. }\end{array}$ & & \\
\hline & buku/ noaialah. & 3 & 1,5 \\
\hline & Keluarga & 40 & 20,4 \\
\hline & acang tua dan teman. & $>1$ & 36,2 \\
\hline & tidak darisiapapun & 21 & 10,7 \\
\hline & TV/internet & 61 & 3,1 \\
\hline \multirow[t]{4}{*}{7} & Derajat Dismenoce & & \\
\hline & nxericingan & 101 & 51,5 \\
\hline & Dxerisedang & 79 & 40,3 \\
\hline & axeriberat & 16 & 8,2 \\
\hline \multirow[t]{3}{*}{8} & Berabat ke Dokter. & & \\
\hline & Tidak & 180 & 91,8 \\
\hline & Ya & 16 & 8,2 \\
\hline
\end{tabular}




\section{Prosiding Seminar Nasional Kesehatan \\ Lembaga Penelitian dan Pengabdian Masyarakat Universitas Muhammadiyah Pekajangan Pekalongan

\section{Tingkat Pengetahuan Responden tentang Swamedikasi Antipiretik}

1. Tingkat pengetahuan siswi pada saat pretest dan posttest

Tabel 2. Distribusi frekuensi tingkat pengetahuan dari seluruh siswi pada saat pretest dan posttest

\begin{tabular}{lcccc}
\hline & Pretest & \multicolumn{3}{c}{ post test } \\
\cline { 2 - 5 } Pengetahuan & Frekuensi & Persen\% & Frekuensi & Persen\% \\
\hline Baik & 154 & 78,6 & 173 & 88,3 \\
Cukup & 28 & 14,3 & 22 & 11,2 \\
Kurang & 14 & 7,1 & 1 & 5 \\
Total & 196 & 100 & 196 & 100 \\
\hline
\end{tabular}

Dari Tabel 2 dapat diketahui bahwa pada saat pretest sebagian besar responden termasuk dalam kategori pengetahuan baik yaitu $78,6 \%$ dan sebelah diberikan edukasi menggunakan leaflet pada saat posttest terdapat peningkatan sebanyak $88,3 \%$ yang termasuk dalam kategori pengetahuan baik.

2. Sikap siswi pada saat pretest dan posttest

Tabel 3. Distribusi Frekuensi sikap dari seluruh siswi pada saat pretest dan posttestt

\begin{tabular}{lcccc}
\hline & Pretest & \multicolumn{3}{c}{ post test } \\
\cline { 2 - 5 } \multicolumn{1}{c}{ Sikap } & Frekuensi & Persen\% & Frekuensi & Persen\% \\
\hline Sikap Positif & 190 & 96,9 & 194 & 99 \\
Sikap Negatif & 6 & 3,1 & 2 & 1,0 \\
Total & 196 & 100 & 196 & 100 \\
\hline
\end{tabular}

Dari tabel 3 dapat diketahui Sikap swamedikasi dismenore dengan obat tradisional (jamu kunyit asam) pada saat pretest sebagian besar didapatkan kategori sikap positif sebanyak 96,9\% dan setelah diberikan edukasi menggunakan leaflet pada saat posttest terdapat peningkatan sebanyak $99 \%$ yang termasuk kategori sikap positif.

3. Uji Normalitas

Tabel 4. Untuk mengetahui apakah data pretest dan posttest saling berdistribusi normal perlu dilakukan uji normalitas

\begin{tabular}{|c|c|c|c|c|c|c|}
\hline \multicolumn{7}{|c|}{ Tests of Normality } \\
\hline & \multicolumn{3}{|c|}{ Kolmogorov-Smirnov ${ }^{\mathrm{a}}$} & \multicolumn{3}{|c|}{ Shapiro-Wilk } \\
\hline & Statistic & $\mathrm{df}$ & Sig. & Statistic & $\mathrm{df}$ & Sig. \\
\hline Pre & .471 & 196 & .000 & .528 & 196 & .000 \\
\hline \multicolumn{7}{|c|}{ Pengetahuan } \\
\hline Post & .522 & 196 & .000 & .382 & 196 & .000 \\
\hline \multicolumn{7}{|c|}{ Pengetahuan } \\
\hline Pre Sikap & .540 & 196 & .000 & .162 & 196 & .000 \\
\hline Post Sikap & .530 & 196 & .000 & .075 & 196 & .000 \\
\hline
\end{tabular}




\section{Prosiding Seminar Nasional Kesehatan Lembaga Penelitian dan Pengabdian Masyarakat Universitas Muhammadiyah Pekajangan Pekalongan}

Dari Tabel 4 hasil dari uji normalitas dapat diketahui hasil dari nilai Asymp.Sig sebesar 0,000. Dapat diartikan bahwa nilai tersebut lebih kecil dari 0,05 sehingga dapat disimpulkan bahwa uji normalitas tersebut terdistribusi tidak normal, sehingga uji selanjutnya adalah uji non parametrik yaitu uji Wilcoxon.

\section{Pengaruh leaflet Metode FGD Terhadap Pengetahuan Swamedikasi Antipiretik}

Tabel 5. Pengaruh leaflet terhadap pengetahuan siswi dalam swamedikasi dismenore dengan obat tradisional (jamu kunyit asam)

Test Statistics ${ }^{\mathrm{a}}$

\begin{tabular}{lr}
\hline & $\begin{array}{r}\text { Post Pengetahuan - Pre } \\
\text { Pengetahuan }\end{array}$ \\
\hline$Z$ & $-3.654^{\mathrm{b}}$ \\
Asymp. Sig. (2-tailed) & .000 \\
\hline a. Wilcoxon Signed Ranks Test & \\
b. Based on positive ranks. & \\
\hline
\end{tabular}

Dari hasil tabel 5 diperoleh nilai signifikansi pengetahuan responden pretest dan postest yaitu $<0,05$ dengan nilai Sig. (2-tailed) 0,000 yang berarti terdapat perbedaan pengetahuan antara sebelum dan sesudah diberikan leaflet, sehingga dapat disimpulkan bahwa pemberian leaflet berpengaruh terhadap pengobatan keluhan dismenore dengan Obat Tradisional (Jamu Kunyit Asam) di SMA negeri 3 pemalang terhadap Pengetahuan karna nilai sig 0,000 < 0,05.

Tabel 6. Pengaruh leaflet terhadap sikap siswi dalam swamedikasi dismenore dengan obat tradisional (jamu kunyit asam)

\begin{tabular}{lr}
\multicolumn{2}{c}{ Test Statistics $^{\text {a }}$} \\
\hline & Post Sikap - Pre Sikap \\
\hline Z & $-2.000^{\text {b }}$ \\
Asymp. Sig. (2-tailed) & .046 \\
\hline
\end{tabular}

a. Wilcoxon Signed Ranks Test

b. Based on positive ranks.

Pada Tabel 6 diperoleh nilai signifikansi sikap responden pretest dan posttest yaitu <0,05 dengan nilai Sig. (2-tailed) 0,046 yang berarti terdapat perbedaan sikap antara sebelum dan sesudah diberikan leaflet, sehingga dapat disimpulkan bahwa pemberian leaflet berpengaruh terhadap pengobatan keluhan dismenore dengan Obat Tradisional Jamu Kunyit Asam di SMA Negeri 3 Pemalang terhadap sikap karna nilai sig $0,046<0,05$.

\section{Pembahasan}

\section{Karakteristik Responden}

Karakteristik umum responden menunjukkan bahwa sebagian besar sumber informasi yang telah didapatkan untuk melakukan swamedikasi dismenore sebagian besar responden mendapatkan sumber informasi dari orang tua dan teman sebanyak 71 responden $(36,2 \%)$ Menurut penelitian yang dilakukan oleh [6]. menyatakan bahwa 


\section{Prosiding Seminar Nasional Kesehatan 2021 Lembaga Penelitian dan Pengabdian Masyarakat Universitas Muhammadiyah Pekajangan Pekalongan}

keluarga, teman dan kenalan merupakan media paling efektif dalam pencarian informasi tentang pelayanan pengobatan obat tradisional. Hasil yang didapat sebanyak $71(36,2 \%)$ dari orang tua dan teman dikarenakan orang tua selalu dekat dan mengawasi anak perempuan pada saat dismenore dan memberikan informasi untuk mengobati dismenore.

\section{Tingkat Pengetahuan responden dalam swamedikasi dismenore dengan obat tradisional (jamu kunyit asam)}

Tingkat pengetahuan pada siswi SMA Negeri 3 Pemalang mengenai swamedikasi dismenore dengan obat tradisional (jamu kunyit asam) dapat dilihat pada tabel menunjukkan bahwa tingkat pengetahuan saat pretest sebagian besar didapatkan kategori baik sebanyak 154 responden. Salah satu penyebab yang membuat tingkat pengetahuan responden baik karena responden memiliki tingkat pendidikan SMA Menurut [10]. semakin tinggi pendidikan seseorang, semakin mudah untuk menerima informasi. Ada juga faktor lain dari sumber informasi obat yang diperoleh responden.

Tingkat pengetahuan setelah diberikan edukasi menggunakan leaflet Tingkat pengetahuan setelah posttest didapatkan kategori baik sebanyak 173 responden. mengenai swamedikasi dismenore dengan obat tradisional (jamu kunyit asam) mengalami peningkatan pada kategori baik. Hal ini dapat disimpulkan bahwa peningkatan persentase ini membuktikan pemberian informasi kepada responden berhasil meningkatkan pengetahuan tentang swamedikasi terhadap pengobatan keluhan dismenore dengan obat tradisional (jamu kunyit asam) yang artinya siswi mempunyai pengetahuan terhadap swamedikasi dismenore menggunakan obat tradisional (jamu kunyit asam).

\section{Sikap responden dalam swamedikasi dismenore dengan obat tradisional (jamu kunyit asam)}

Sikap swamedikasi terhadap pengobatan keluhan dismenore dengan obat tradisional (jamu kunyit asam) dapat dilihat pada tabel menunjukkan bahwa sikap responden saat pretest sebagian besar didapatkan kategori sikap positif sebanyak 190 responden. Sikap responden setelah posttest didapatkan kategori sikap positif sebanyak 194 responden. Hal ini dapat disimpulkan bahwa peningkatan persentase ini membuktikan pemberian informasi kepada responden berhasil meningkatkan sikap tentang swamedikasi terhadap pengobatan keluhan dismenore dengan obat tradisional (jamu kunyit asam). Faktor lain yang dapat mempengaruhi sikap adalah pengaruh orang lain yang dianggap penting [11]. Menyatakan bahwa media massa seperti televisi, radio, surat kabar, majalah, internet dan lain-lain mempunyai pengaruh besar dalam pembentukan sikap. Penanganan adalah perilaku yang ditunjukkan untuk melakukan suatu tindakan. Pengetahuan merupakan hasil tahu seseorang terhadap objek melalui indra yang dimilikinya, sedangkan pengetahuan merupakan faktor yang mempengaruhi persepsi dan perilaku remaja yang berupa penanganan terhadap dismenore, sehingga pengetahuan sangat penting untuk membentuk perilaku seseorang. 


\section{Prosiding Seminar Nasional Kesehatan Lembaga Penelitian dan Pengabdian Masyarakat Universitas Muhammadiyah Pekajangan Pekalongan}

\section{Pengaruh leaflet terhadap pengetahuan siswi dalam swamedikasi dismenore dengan obat tradisional (jamu kunyit asam)}

Berdasarkan hasil dari uji normalitas dapat diketahui hasil dari nilai Asymp.Sig sebesar 0,000. Dapat diartikan bahwa nilai tersebut lebih kecil dari 0,05 sehingga dapat disimpulkan bahwa uji normalitas tersebut terdistribusi tidak normal, sehingga uji selanjutnya adalah uji non parametrik yaitu uji Wilcoxon.

\section{Pengaruh leaflet terhadap sikap siswi dalam swamedikasi dismenore dengan obat tradisional (jamu kunyit asam)}

Pengaruh leaflet dengan metode Pra experimental dengan menggunakan rancangan penelitian one group pretest - posttest design. Terhadap pengetahuan dan sikap siswi dalam swamedikasi dismenore dengan obat tradisional (jamu kunyit asam) dapat dilihat dari nilai pretest dan postest. Dari hasil tabel 5 diperoleh nilai signifikansi pengetahuan responden pretest dan postest yaitu $<0,05$ dengan nilai Sig. (2-tailed) 0,000 yang berarti terdapat perbedaan pengetahuan antara sebelum dan sesudah diberikan leaflet, sehingga dapat disimpulkan bahwa pemberian leaflet berpengaruh terhadap pengobatan keluhan dismenore dengan Obat Tradisional (Jamu Kunyit Asam) di SMA negeri 3 pemalang terhadap Pengetahuan karna nilai sig 0,000 0,05.

Dari hasil tabel 6 diperoleh nilai signifikansi sikap responden pretest dan posttest yaitu <0,05 dengan nilai Sig. (2-tailed) 0,046 yang berarti terdapat perbedaan sikap antara sebelum dan sesudah diberikan leaflet, sehingga dapat disimpulkan bahwa pemberian leaflet berpengaruh terhadap pengobatan keluhan dismenore dengan Obat Tradisional Jamu Kunyit Asam di SMA Negeri 3 Pemalang terhadap sikap karna nilai sig 0,046 0,05.

Hasil penelitian ini menunjukkan bahwa leaflet mempengaruhi pengetahuan. Selain pemberian informasi, pada penelitian ini sesuai dengan pernyataan menurut [12]. yang mempengaruhi pengetahuan juga terdapat beberapa faktor yakni: usia, pendidikan, lingkungan, intelegensia, pekerjaan, informasi, sosial budaya dan ekonomi dan pengalaman.

Faktor yang mempengaruhi sikap adalah pengetahuan, pengalaman pribadi, pengaruh orang lain, budaya, media massa, lembaga pendidikan dan genetik [11]. Sedangkan faktor yang mempengaruhi pengetahuan yaitu pendidikan, pengalaman, informasi, budaya, dan pekerjaan. Sikap yang ditunjukkan remaja putri tergantung dari pengetahuan yang ia miliki. Pengetahuan tentang dismenore sangat berpengaruh terhadap sikap dalam mengatasi dismenore.

\section{Kesimpulan}

Berdasarkan penelitian menunjukkan bahwa pertama terdapat peningkatan pengetahuan swamedikasi dismenore dengan obat tradisional (jamu kunyit asam) di SMA Negeri 3 Pemalang setelah diberikan edukasi menggunakan media Leaflet. Kedua Terjadi perubahan sikap dalam mengatasi swamedikasi dismenore dengan obat tradisional (jamu kunyit asam) di SMA Negeri 3 Pemalang Setelah diberikan edukasi menggunakan media Leaflet. Dalam penelitian ini terdapat pengaruh antara pengetahuan dan sikap siswi dalam swamedikasi dismenore dengan obat tradisional 


\section{Prosiding Seminar Nasional Kesehatan 2021 Lembaga Penelitian dan Pengabdian Masyarakat Universitas Muhammadiyah Pekajangan Pekalongan}

(jamu kunyit asam) di SMA Negeri 3 Pemalang tahun 2021 karena nilai Asymp. Sig $0,000<0,05$.

\section{Referensi}

[1] Kusmiati, A., \& Herliningsih, H. 2018. Gambaran Pengetahuan Siswi Kelas X dan XI Terhadap Swamedikasi Menggunakan Obat Herbal Kunyit Dan Asam Jawa Untuk Keluhan Dismenorea Di SMKN " $X "$ Di Kabupaten Kuningan. Jurnal FARMAKU (Farmasi Muhammadiyah Kuningan), 3(1), 18-28.

[2] Lei $X$, Jiang $H$, Liu C, Ferrier $A$, et al. 2018. Self-medication practice and associated factors among residents in Wuhan, China. Int. J. Environ. Res.Publi Health,15(1), p.68.

[3] WHO. 2013. Data Jumlah Penderita Dysmenorrhea. Diakses pada 8 November 2017. Notoatmodjo, S, "Ilmu Perilaku Kesehatan," 2014. Jakarta: Rineka Cipta.

[4] Laila, Rahmawati \& Atik. (2011). Pengaruh kunyit asam terhadap penanganan nyeri haid pada siswi Kelas XI SMA Negeri I Sugihwaras.

[5] Asroyo, T., Nugraheni, T. P., \& Masfiroh, M. A. 2019. Pengaruh Pemberian Minuman Kunyit Asam Sebagai Terapi Dismenore Terhadap Penurunan Skala Nyeri. Indonesia Jurnal Farmasi, 4(1), 24-28.

[6] Mulyani, H., Widyastuti, S. H., \& Ekowati, V. I. 2016. Tumbuhan herbal sebagai jamu pengobatan tradisional terhadap penyakit dalam serat primbon jampi jawi jilid I. Jurnal Penelitian Humaniora Uny, 21(2), 124817.

[7] Sholekhudin, M. 2014. Buku Obat Sehari-hari. Jakarta: PT. Gramedia.

[8] McPhee, Stephen dan Ganong, William. 2013. Patofisiologi Pemyakit Pengantar Menuju Kedokteran Klinis. Jakarta : EGC.

[9] Proverawati. 2014. Menarche Menstruasi Pertama Penuh Makna. Yogyakarta : Mutiara Medika.

[10] Budiman \& Riyanto A. 2013 . Kapita Selekta Kuesioner Pengetahuan Dan Sikap Dalam Penelitian Kesehatan. Jakarta : Salemba Medika

[11] Azwar, Saifuddin. 2013. Sikap Manusia Teori dan Pengukurannya Cetakan XVIII. Yogyakarta: Pustaka Belajar.

[12] Notoajmadjo, S. 2014. Ilmu Perilaku Kesehatan. Jakarta: PT. Rineka Cipta.

[13] Priyatno, D. 2016. SPSS Handbook : Analisis Data, Olah Data \& Penyelesaian Kasus-Kasus Statistik. Yogyakarta: Mediakom.

[14] Nursalam. 2013. Metodologi Penelitian IImu Keperawatan Pendekatan Praktis.Jakarta: Salemba Medika.Sholekhudin, M. 2014. Buku Obat Sehari-hari. Jakarta: PT. Gramedia.

[15] Sugiyono. 2013. Metode Penelitian Kuantitatif Kualitatif dan $R \& D$. Cetakan XVIII. Bandung: Alfabeta 